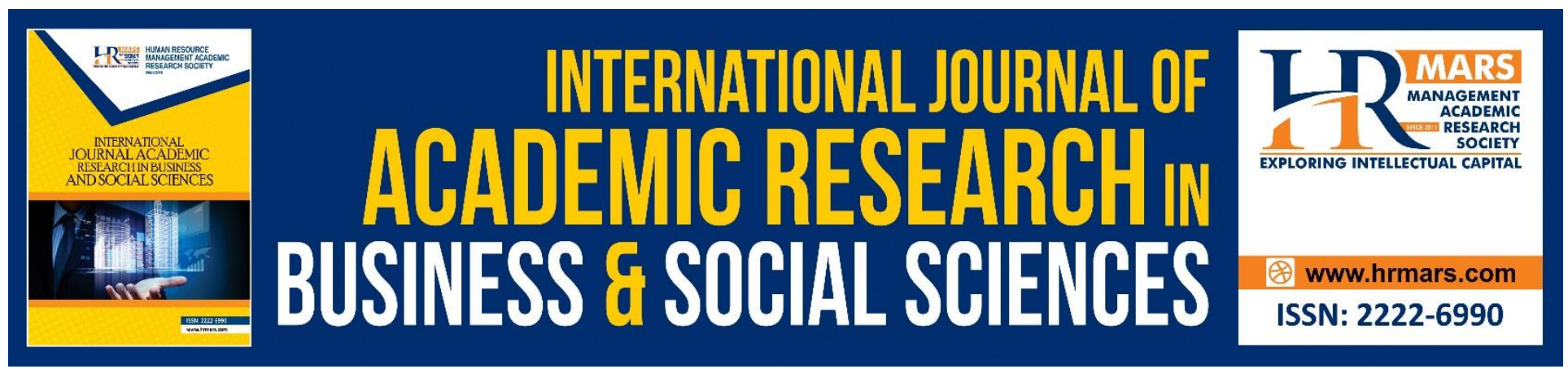

\title{
Abu Bakr Al-Bayhaqi and his Approach to Sifat Traditions
}

\section{Umar Muhammad Noor}

To Link this Article: http://dx.doi.org/10.6007/JJARBSS/v9-i6/5951

DOI: $10.6007 /$ IJARBSS/v9-i6/5951

Received: 19 April 2019, Revised: 26 May 2019, Accepted: 03 June 2019

Published Online: 29 June 2019

In-Text Citation: (Noor, 2019)

To Cite this Article: Noor, U. M. (2019). Abu Bakr Al-Bayhaqi and His Approach to Sifat Traditions. International Journal of Academic Research in Business and Social Sciences, 9(6), 326-336.

Copyright: (C) 2019 The Author(s)

Published by Human Resource Management Academic Research Society (www.hrmars.com)

This article is published under the Creative Commons Attribution (CC BY 4.0) license. Anyone may reproduce, distribute, translate and create derivative works of this article (for both commercial and non-commercial purposes), subject to full attribution to the original publication and authors. The full terms of this license may be seen

at: http://creativecommons.org/licences/by/4.0/legalcode

Vol. 9, No. 6, 2019, Pg. 326 - 336

http://hrmars.com/index.php/pages/detail/IJARBSS

JOURNAL HOMEPAGE

Full Terms \& Conditions of access and use can be found at http://hrmars.com/index.php/pages/detail/publication-ethics 


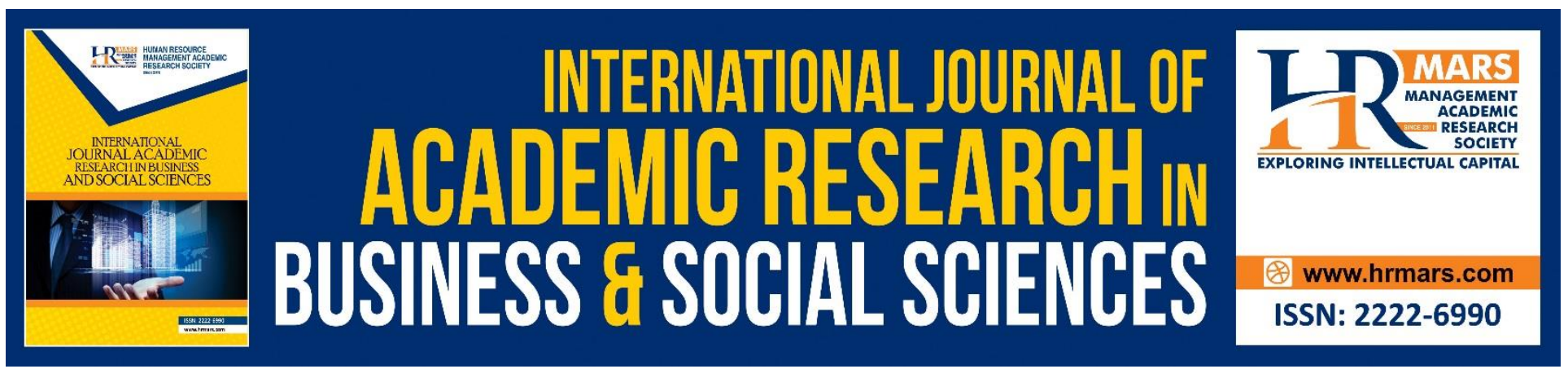

\title{
Abu Bakr Al-Bayhaqi and his Approach to Sifat Traditions
}

\author{
Dr. Umar Muhammad Noor \\ Islamic Studies Section, School of Humanities, Universiti Sains Malaysia, Penang
}

\begin{abstract}
The sifat traditions (ahadith al-sifat) is a term that refers to certain prophetic sayings with ostensibly anthropomorphic content. In dealing with such traditions, most traditionalists (ahl al-hadith) of the 3rd and 4th/9th and 10th century applied an approach that accepts its literal meaning without questioning how (bila kayfa). In the mid-5th/11th century, however, a Nishapurian traditionalist Abu Bakr Ahmad bin Husayn al-Bayhaqi (d. 458/1066) turns to a new approach by which he interpreted certain sifat traditions in a figurative way. This paper aims to offer an in-depth analysis on al-Bayhaqis methodology as demonstrated in his book titled al-Asma wa al-Sifat. By applying historical method, I will uncover the socio-political background in which he suggested a modification in dealing with sifat traditions. I found that unlike most of his contemporaries al-Bayhaqi had combined both traditionalist and rationalists scholarship to deal with problematic content in sifat traditions. By applying distinctive separation between mutawatir and ahad, he accepts 'without how (bila kayfa)' anthropomorphic descriptions in mutawatir traditions as divine attributes, but interprets figuratively the descriptions in ahad traditions unless it fulfils certain criteria. I also found that al-Bayhaqis approach is actually a response to the traditionalists incapability to face theological challenges in the context of Shia political triumph.
\end{abstract}

Keywords: Anthropomorphism, Asharites, Hanbalites, Traditionalist, Divine Attributes.

\section{Introduction}

The sifat traditions (ahadith al-sifat) is a term that refers to prophetic sayings that contains God description in strikingly human terms. Debates on how these traditions should be understood have been bitterly contested among theologians since $3 / 8$ century up to modern time. The rationalists ( $a \mathrm{hl}$ al-ray), represented by the Mutazilites, generally perceive such traditions have contradicted to basic principles of Islamic theology that emphasizes Gods transcendence and radical otherness. Therefore, they advocate a skeptical approach to examine sifat traditions using their speculative reasoning. Regardless of the status of its isnad (chain of transmission), they accept only traditions with possible figurative interpretation and reject others as false. They also used negative labels such as hashwiyya (the rabble), ahl al-taqlid (the blind followers) and nabita (the naïve ones) to any traditionalist who 
INTERNATIONAL JOURNAL OF ACADEMIC RESEARCH IN BUSINESS AND SOCIAL SCIENCES Vol. 9, No. 6, June, 2019, E-ISSN: 2222-6990 @ 2019 HRMARS

circulates anthropomorphic reports without criticizing its content (Ibn Qutaybah 1985; El-Omari 2002).

On the other hand, the traditionalists (ahl al-hadith) generally accepted all descriptions mentioned in sifat traditions provided that the isnad (chain of transmission) is sound. Despite rejecting the concept of tashbih (likening God to mortals), they consider the literal meaning of such traditions without questioning how (bila kayfa). Williams (2009) calls this approach as transcendent anthropomorphism. However, under the heated theological debates in 4th and 5th/10th and 11th century, the bila kayfa strategy eventually takes on a form that resembles tashbih. Holding negative perception on speculative theology, most of the major traditionalists at that time censure all forms of figurative interpretation (tawil). They advocated the obligation to understand literally the anthropomorphic terms in sifat traditions without specifying its modality. In addition to that, they deducted new concepts based on their understanding from the descriptions mentioned in such traditions. For example, not only saying that God "descends to the lowest heaven (yanzilu ila sama al-dunya)" as mentioned literally in hadith, they went on to establish concepts implied from the term descend, which is a form of movement (harakah) and place (makan). Therefore, they stated that God resides in certain place and moves freely as He wants. In his refutation to al-Marisi, al-Darimi (2014) declares that God "is free to do what He wants, He moves if he wants to, (He) descends and ascends if He wants to, grasps and open (His palm), as well as rises and sits if He wants to." Similar statements can be seen in the expositions of Khuzaymah (1992) and Al-Farra $(1410 \mathrm{H})$.

However, a prominent traditionalist and Shafiite scholar of Nishapur, Abu Bakr Ahmad bin alHusayn al-Bayhaqi (d. 458/1066) breaks the tradition and offers an alternative approach which is based on the concept of incomparability (tanzih). He heavily discusses the matter in his book titled al-Asma wa al-Sifat. Having a clear conception on what are appropriate and inappropriate attributes to be predicated to God, al-Bayhaqi accepts without how certain descriptions as divine attributes and interprets the others figuratively. As mentioned by Adem (2015), his method undeniably represents an important transition from the pre-Asharite generation into the classical Asharite synthesis of Nishapur Shafiism which went on to have much influence. Nonetheless, questions on how and why he prefer this approach remains unclear.

This paper aims to demonstrate and examine al-Bayhaqis method in dealing with sifat traditions as well as to shed light on its socio-political background. The study will contribute to the modern literature on hadith studies and Islamic theology in at least three significant aspects. Firstly, it elucidates an understudied Asharite-Shafiite traditionalist methodology in dealing with sifat traditions. Discussions on the topic in modern studies mostly focused on Hanbalite-traditionalist exponents like Ibn Taymiyya and his disciple Ibn al-Qayyim (see for example Holtzman 2010; Ovadia 2018). Less has been contributed to explain Shafii-Asharite traditionalist stance on the matter. Secondly, it presents a missing piece in the history of Asharism from Nishapurian traditionalist angle that is often overlooked in studies on Asharite movement. Thirdly, it explains socio-cultural factors behind the radical transition from Hanbalite-traditionalist hegemony in theological discourse into the rising of Asharism in Sunni-state of Nishapur.

I will argue that al-Bayhaqi has contributed to a significant reform in how the traditionalists should deal with the sifat traditions. Unlike most of his traditionalist peers, he heavily relies on reflective reasoning (nazar) to examine hadith content rendering it compatible with Islamic 
theological concepts. He emphasizes the importance of mutawatir and ahad differentiation, then accepts the descriptions mentioned in the first as divined attributes, and tends to interpret the descriptions mentioned in the latter in a figurative way in line with its semantic meanings. I will also argue that al-Bayhaqis approach is mainly motivated by general perception that the traditionalists were unable to defend Sunnism in the face of strong anti-hadith current at that time.

To prove it, I will discuss the topic in the following order. Firstly, I will conduct a brief study on al-Bayhaqis thought and intellectual life. I will then elucidate and examine his methodology when dealing with the problematic contents in Sifat traditions. Lastly, I will contextualize al-Bayhaqis approach by placing it back into its actual context, namely the Muslim community in the 5th/11th century and the challenges they faced.

\section{Al-Bayhaqis Intellectual Model}

Abu Bakr Ahmad bin al-Husayn al-Bayhaqi was born in 384/994 in Bayhaq (now Sabzevar, Iran). He died at age 71 and was buried at his hometown in 458/1066. According to al-Hamawi (2011), Bayhaq at that time is included in the districts of Nishapur. After completing his Quranic studies, al-Bayhaqi continues his study by learning hadith sciences at an early age. He was 15 when he embarked his first travel (rihla) for hadith collection. He went to various cities within Khorasan, then Baghdad and Kufah, before he proceeded to Hijaz. He also travelled several times to mountainous cities (jibal) in eastern Iran such as Asfahan and Ray. He received Islamic knowledge from up to 100 authoritative scholars with different backgrounds. The list of their names shows diversity in fields of expertise as well as schools of thought which includes traditionalists, jurists and theologians. However, the most influential figure in al-Bayhaqis scholarship is Abu Abd Allah Muhammad bin Abd Allah al-Hakim (d. 405/1014), the grand master of hadith in Nishapur and the author of al-Mustadrak Ala al-Sahihayn. Al-Bayhaqi mastered all of his teachers works and followed faithfully his model of scholarship (AlSubki 1999).

In 441/1051, al-Bayhaqi was invited to Nishapur to head a madrasa (Islamic college) in which he was appointed as professor of hadith. His presence elevated the institutions credential to the extent that it was known among students as Madrasa Bayhaqiyya (the al-Bayhaqi College). Many well-known scholars have graduated from this madrasa including the famous theologian Imam alHaramayn al-Juwayni (d. 478/1085). Al-Subki (1999) stated that al-Juwayni studied theology in this college under the supervision of Abu al-Qasim al-Isfirayini.

Despite his strong affiliation with traditionalists (ahl al-hadith), al-Bayhaqi did not censure speculative theology ( $/ \mathrm{lm}$ al-Kalam). In fact, he was actively involved in theological debates and authored polemical treatises such as Kitab al-Qadr (The Book of Predestination), Hayat al-Anbiya fi Quburihim (The Life of Prophets in their Graves), and Ithbat al-Ruyah (establishing the Beautific Vision). Al-Bayhaqi (nd.) asserted that kalam condemnation in the sayings of previous scholars (Salaf) should not be understood as general prohibition. It was actually addressed to a specific method used by Sunna opponents in their rejection to hadith.

For al-Bayhaqi, it is a traditionalists obligation to apply rational thinking in traditions as part of content analysis to arrive at well-reasoned opinions. He (1986) utterly criticized traditionalists who "glorify elevated isnad (ali al-isnad) and felt contended with hadith transmission formalities while neglecting content analysis (al-dirayah)." Therefore, he has no hesitation to accept Asharite semi- 
rationalism in his effort to defend the Sunnah. He received Asharism from several authorities including Abu Bakr Ibn Furak who studied kalam under Abu al-Hasan al-Bahili, a direct disciple of the founder of Asharism Abu al-Hasan al-Ashari (d. 324/936). In addition, when Asharites underwent political oppression in Nishapur by the Seljuqs authorities, al-Bayhaqi sent a lengthy letter to Vizier al-Kunduri to convince him that Asharism is not heresy. In fact, the founder of Asharism was nothing else but a defender of Sunnah who used rationalism as a weapon (al-Subki 1999).

Reading al-Bayhaqis theological works, one could observe his persistence in incorporating alShafiis opinion in theological issues. He did it either by reporting al-Shafiis explicit sayings on the matter or by abstracting al-Shafiis opinion in theological issues from his legal rulings. By doing so, alBayhaqi clearly tried to depict al-Shafii as an expert in theology as well as to show compatibility between Asharis rationalism and Shafiis legal principles. His intention most likely was to legitimize Asharism in the eyes of some Shafiite-traditionalists who are apparently skeptical over this new movement. His effort in many ways has contributed to the later perceived triumph of Asharite movement in Nishapur and Baghdad under the patronage of the Saljuqi Vazier Nizam al-Mulk, as well as paving the way for later Asharite proponents such as Ibn Asakir and Ibn al-Subki to continue spreading Asharism in Shafiite-traditionalist circles (see Makdisi 1962).

Al-Bayhaqis scholarship clearly differs from the typical traditionalist of 5th/11th century. He represents a new school of thought that offers a synthesized-form of scholarship that amalgamates the best quality of both the traditionalists and the rationalists. He discards negative tendency towards rationalists and their speculative method. This notion prevails in his various works and discussions, and certainly leaves impact in his discussion on sifat traditions as we will discuss in the following.

\section{Al-Bayhaqi on Sifat Traditions}

Al-Bayhaqi heavily discusses sifat traditions in his extensive work titled al-Asma wa al-Sifat (Gods Divine Names and Attributes). His authorship is unquestionable as it is profusely associated to him in various bibliographic dictionaries (See for instance al-Dhahabi 1986; al-Subki 1999; Khalifah nd.; alFulani 1328). The books objective is to establish Gods appropriate names and attributes based on clear and undisputed statements stemming from al-Quran, mutawatir hadiths and the consensus of the pious predecessors (ijma al-Salaf). By authoring this book, al-Bayhaqi (2002) intends to provide assistance to his fellow Sunni-theologians (mutakallimu ahl al-sunnah), whose expertise in hadith criticism is limited, in their effort to defend Sunnism. Therefore, his contribution is met with open arms. When Nishapur theologian Abu Mansur bin Abi Ayyub heard about the project, he was fascinated and urged al-Bayhaqi to immediately finish the book. But due to inevitable circumstances, the book was only completed a few years after the death of Ibn Abi Ayyub.

Al-Bayhaqis book demonstrated significant transition from traditionalist conservative approach in dealing with anthropomorphic terms in traditions. He actively enumerated on such traditions which most of past traditionalists hardly did. In order to legitimize his approach, al-Bayhaqi (2002) presented a hadith from Abu Hurayrah in which he reported that the Prophet said:

"Verily, Allah will say on the Day of Resurrection: O son of Adam, I was sick but you did not visit me. The man will say: O Lord, how could I visit you? You are God of the universe? Allah said: Did you not know that my servant was sick but you did 
INTERNATIONAL JOURNAL OF ACADEMIC RESEARCH IN BUSINESS AND SOCIAL SCIENCES Vol. 9, No. 6, June, 2019, E-ISSN: 2222-6990 @ 2019 HRMARS

not pay a visit to him? Do you not know that if you attended him, you will have found me by his side?"

The hadith contains proposition for two basic principles in Sunni theological discourse. First, it indirectly offers permissibility to discuss the unclear statements regarding Gods attributes. The formula is taken from explicit question and answer between man and God regarding the actual meaning of the word "sick". Second, it indicates that sometimes a word stated in a prophetic tradition should not be understood literally. Instead it should be interpreted figuratively. Although the word "sick" is attributed to God, it actually refers to one of His servants.

Al-Bayhaqi confirms the fact that past traditionalists refrained from commenting the content of sifat traditions. Nevertheless he insists that they unconditionally rejected corporeality (tasbih) in their silence. In any chance they will not liken God to humans in His divine attributes or actions. Upon hearing the sifat traditions, their mind instantly captures the main message conveyed initially in the traditions without affirming the inappropriate attributes to God. For example, when they read a hadith stating that the heavens will be folded on Gods finger on the Resurrection Day, they are directly inspired by Gods glory and unlimited power. But it never occurs to them that God has physical finger as one of His divine attributes. However, this condition eventually changes when later traditionalists misunderstood the hadiths due to their lack of expertise in Arabic lexicography. Therefore, scholars needed to address the issue in a way that disregards tashbih and offer interpretations that are in line with the principles of Islamic belief.

Because of its crucial position in Islamic faith, the establishment of divine attributes demands authoritative proofs that leaves no room for doubt (qați). Therefore, only proofs that belong to the highest degree of conviction namely al-Quran, Sunna and the consensus of umma (ijma) are accepted. By the term of Sunna, al-Bayhaqi means the mutawatir which is a certain type of tradition that is transmitted through sufficient number of isnads to preclude any possibility of forgery. He asserted that any predication conveyed by mutawatir reports and is compatible to reason, must be accepted as Gods attributes without questioning how (bila kayfa). We can see the application of this method when he affirms eight conceptual attributes (sifat al-maani) for God, namely qudrah (power), sam (hearing), basar (sight), kalam (speak), ilm (knowledge), hayah (life), and baqa (eternality). He also applied it when establishing the attributes of face (wajh), eye (ayn) and hand (yad). He asserted (1988): "These attributes are informed via revelation (sam), we accept it since it was brought by a reliable informant (Prophet), nonetheless, we do not specify its modality (la nukayyifuha)."

In regards to what is considered as anthropomorphic descriptions in ahad traditions, al-Bayhaqi shows reasonable caution. He did not directly accept the description as a divine attribute unless it fulfils certain requirements. First of all, its isnad (chain of transmission) must be proven as authentic. And secondly, the terms used in the matn (text) must be validated with explicit statements originating from al-Quran or mutawatir traditions. It is celar that al-Bayhaqi does not consider ahad traditions as an independent proof in discourses regarding divine attributes. Without support from undisputable proofs, the problematic content in ahad traditions should be interpreted figuratively. This method is prevalent in his discussions about anthropomorphic descriptions such as "the soul (nafs)", "the finger (usbu)," "the foot (qadam /rijl)," and "the shape (surah)", "the laugh (al-dahk)," "the walk (harwalah)", and "the shy (haya)". He pointed out that these descriptions, which are transmitted through ahad traditions and are not supported by explicit statements from al-Quran and mutawatir 
traditions, should be interpreted in line with its semantic meanings rather than seen as Gods divine attributes.

In this particular point, al-Bayhaqi differs from most of his traditionalist peers who apply no distinction between ahad and mutawatir traditions in theological discourse. Some of them are Nishapurian traditionalist who, like him, belongs to the Shafiite school. In his Kitab al-Tawhid, Ibn Khuzaymah expresses stern acceptance for all kinds of descriptions in sifat traditions without any exception. He boldly stated that establishing anthropomorphic terms as mentioned in hadiths do not count as an act of tashbih so long as it is done without comparing God to humans. He (1992) said: "We affirm that God has two hands, both are right none of it is left, because the Quran has told us that God has two hands. The Prophet also said that those hands are right sided, no left sided attributed to Him. We also concur that a perfect human body has two hands, right sided and left sided. Nonetheless, we do not say that human hands are similar like those in The Creator."

In his justification, al-Bayhaqi (2002) explains that ahad traditions, though accepted as sound, to a certain degree still leaves the possibilities for human error. He takes as an example Qatadah bin al-Numans hadith that reports the Prophets saying: "God has taken a rest after creating the universe". First of all, al-Bayhaqi makes it clear that the hadith is categorized as munkar (unacceptable). Even if it is sound, he continues, the conception mentioned in its text is still unacceptable as it contradicts with the statement of al-Quran which clearly says that God has created the universe in six days without any sense of weariness (50:38). It is most likely that the hadith has been taken out of its actual context. The Prophet actually quoted this statement from the people of the book (ahl al-kitab) to express disagreement, but Qatadah misunderstood it. Another version of the hadith which was reported by Zubayr bin al-Awwam clearly stated the actual context of the hadith. Al-Bayhaqi (2002) then stated: "Because of this kind of possibility, our rationalist peers (ahl al-nazar min ashabina) refrained from accepting ahad traditions in topics related to divine attributes if the conception is not supported by al-Quran (al-kitab) and the consensus (ijma), instead they interpret the content figuratively."

Another reason why al-Bayhaqi disapproves ahad traditions as independent proof in theological discussion is in relation to wording accuracy. Due to the wide acceptance of riwayah bi al-mana (hadith narration by its general meaning) among the majority of past transmitters, one can hardly say that the statements contained in ahad traditions reflect the actual words of the Prophet. Especially when it appears to be incompatible with the basic of Islamic beliefs about God. Therefore, al-Bayhaqi strongly encourages the people of knowledge ( $\mathrm{ahl}$ al-ilm) to always exercise caution in extracting meanings from such traditions.

\section{Contextualization of Bayhaqis Approach}

Overall al-Bayhaqis approach to sifat traditions is primarily still in line within the traditionalist theological framework. However, the traditionalist-Hanbalites until recent time have considered this approach as a deviation from the way of the pious predecessor (al-salaf al-salih). Modern Salafis alleged that al-Bayhaqis approach is due to the negative influence of his master, Ibn Furak, whose hermeneutical approach tends to corrupt the original meaning of hadith (al-Muallimi 2001, alGhamidi 2002) Discussion as to whether this perception is true or false requires further study. In this paper, I am interested to offer a deeper question: What was the deciding factor that made al-Bayhaqi 
INTERNATIONAL JOURNAL OF ACADEMIC RESEARCH IN BUSINESS AND SOCIAL SCIENCES Vol. 9, No. 6, June, 2019, E-ISSN: 2222-6990 @ 2019 HRMARS

shed a conservative approach for a newer one? To answer this question requires a clear picture on the state of Islamic religious learning during his time.

To many historians, the 4th and 5th / 10th and 11th centuries are considered as the "Shii/Ismaili Centuries." At that time, Shia political dynasties were on the rise and triumphant in most of the Islamic world (Widigdo 2017). In the west, the Ismaili Fatimids took control of Egypt and North Africa and declared their ruler as the Amir al-Muminin (the supreme leader of the Islamic world) to rival the Sunni Abbasid Caliph in Baghdad. At the same time, the Qaramites ruled over many parts of Iraq including Mosul and Madain. The Imami Buyids ruled eastern part of Iran and successfully managed to invade Baghdad in 335/945. The emergence of political Shia posed a serious threat in the face of Sunnism in all over the Islamic countries. The Baghdadi historian Ibn al-Jawzi (1992) recorded several conflicts that occurred between the Sunnis and Shiites in capital city of Baghdad during this particular period of time.

Nisaphur is inarguably one of the last stronghold for Sunnism in the middle of anti-Sunna milieu. Both of its rulers and people have strong adherence to Sunnism and had faithfully maintained their allegiance to the Abbasid Caliphate in Baghdad. Nevertheless, a number of theological schools of thought thrived to compete with the mainstream Sunnism to be a favorable religious path for Nishapurians. The followers of Muhammad bin Karram al-Sijistani, whose teachings were denounced as heretic by most theologians for championing anthropomorphism, have actively spread their influence within the city. The historian al-Dhahabi (1990) stated that the Karramites produced voluminous books of theology to promote and advocate their doctrine. At the same time, the Mutazilites with full support from al-Qadi Abd al-Jabbar, one of most influential Mutazilite scholar of all time, tried to gain strong foothold as well. Abu Rushayd Said bin Muhammad, one of Abd alJabbars senior disciples, resided in Nishapur and facilitated a halaqah (scholar assembly) in periodically (al-Murtada 1961). In addition to the Egyptian Ismailite proponents who sought to extend the Fatimids influence by spreading Shiism within the Nishapur Sunni community. All of these have led to a series of heated theological debates between the followers of the different schools (see Widigdo 2017).

Meanwhile, amidst these socio-religious challenges, the traditionalists have been experiencing an unstoppable decline in their state of scholarship. Unlike the previous scholar of hadith, most of them have no sufficient intellectual qualities that enables them to face the current challenges. Their biggest concern remains in trivial aspects of traditions such as collecting anomalous and isolated transmissions (shawadh wa gharaib al-isnad) with minimal effort focused to comprehend its legal content. In fact, they have developed negative sentiments towards jurist-consults (fuqaha) and theologians (mutakallimin) for using rational and speculative analysis. Observing the state of religious scholarship at his time in Baghdad, al-Khațib al-Baghdadi (nd.; 1971) stated that most students of hadith have minimum ability in distinguishing sound hadiths from the weak ones, as well as in comprehending hadith legal contents. Nevertheless, they refused to learn from the fuqahas. They denounced all kinds of qiyas (logical deduction), without differentiating between the good reasons form the bad one, based on dubious traditions that have utterly censured ray (reason).

Having lack of mastery in rational aspects does not prevent some traditionalists to get themselves involved in theological discourse and refute anti-hadith tendencies. This negligent act did not only ruin their personal credentials, but also the image of the traditionalists as a whole. This was 
what exactly had happened when Hanbali-traditionalist, Harb bin Ismail al-Sirjani, explicitly criticized and condemned anti-Sunna ideologies in his book titled al-Sunnah wa al-Jamaah. The condemnation incited a strong retaliation from the Mutazilite scholar Abu al-Qasim al-Kabi in a way that he not only deflated Sirjanis work but also assaulted the entire hadith scholars. Despite his disagreement with alKabi, the Shafiite-traditionalist Abu Muhammad al-Ramahurmuzi first of all puts blame on Sirjani for entering theological debate which is out of his expertise. He (1984) said that "a man who is only a transmitter (al-rawi al-mujarrad) should not tackle what he does not master. It is more appropriate and excusable for him to leave what does not concern him. In fact, doing so is the path of every knowledgeable man." (El-Omari 2002)

Sirjanis incident is one out of many cases that clearly reflect the traditionalists failure to defend Sunnism on their own. Their literal and anti-rational approach to traditions, as well as their negligence and arrogance, failed to convince Sunna opponents to abandon their heretic thoughts. These factors most likely are also the reasons behind the phenomenon, mentioned by al-Khatțabi (2004), that young students of law (mutafaqihah) at his time have developed certain interest to kalam solution. Realising the brunt of this state, some scholars suggested a reform by offering a perfected-version of traditionalism that combines both traditionalist and rationalist scholastics. In his lengthy preface of Maalim al-Sunan, Abu Sulayman Khațțabi (1932) urges the traditionalists to adopt nazar (reason) and to acquire it from their jurist counterparts. At the same time, he suggested the latter to learn hadith authentication from the first. By the term of nazar, he intended "text-critical study," "forensic examination", and "reflective reasoning", rather than theological speculation. As a traditionalistShafii scholar, Khattabi presents "reflective reasoning" as complementary to, rather than conflicting with, adherence to the "cultural and spiritual legacy" of Prophet Muhammad, his companions, and their immediate followers (Tokatly 2001, Gunther 2008).

Khațtabis preposition paves way for the acceptance of a new approach in sifat traditions among Nisapurian traditionalists. It corresponds with Asharism which has become a new trend in Nishapur and managed to attract strong followers. From the beginning of its movement, the Asharites consider themselves as part of traditionalist community who strive to preserve and defend Sunnism using reflective reasoning (naz̧ar). One of their leaders Abu Bakr Ibn Furak (2005) stated that the traditionalists (ashab al-hadith) consist of two groups, namely the transmitters (ahl al-naql) and the thinkers (ahl al-nazar). The first is known for their respected expertise in hadith transmission and authentication. The latter is known for their skill in deducting arguments from hadiths and defending Sunnah based on solid and clear principles (usul). With their specific area of expertise, both groups are complementing each other. However, in cases of clash of opinions over theological doctrines, the thinkers opinion must be preferred as reflective reasoning is in their realm of expertise.

Al-Bayhaqis approach to sifat traditions clearly is a perpetuation of this emerging trend in Nishapur. He develops and applies al-Khațtabi and Ibn Furaks new concept of traditionalism to produce a distinctive and comprehensive methodology in dealing with ostensibly anthropomorphic terms in traditions. He clearly divided discussions on such traditions into two aspects with two different reference points respectively. When he discusses aspects related to hadiths authentication, he refers to traditionalists belonging in the transmitter group whose expertise in hadith authentication is unquestionable. But when it comes to textual and content analysis, he turns to a different group of scholars in which their expertise is in reasoning. Calling these scholars as "the 
thinkers within our fraternity (ahl nazar min ashabina)," Bayhaqi relies heavily on scholars who has expertise in both tradition and rationalism such as Abu Sulayman al-Khațțabi, Abu Abd Allah al-Halimi, Abu Mansur Ibn Abi Ayyub, and Abu al-Hasan Ali bin Muhammad bin Mahdi.

No single case is found where al-Bayhaqi refers to the transmitter group when examining the problematic descriptions in sifat traditions. In fact, he produces some reports to indicate that these scholars, including Ibn Khuzaymah, have no adequate qualification in theological discussions. In his lengthy explanation about the createdness of human utterance of the Quran (lafz bi al-Quran), Bayhaqi criticizes Ibn Khuzaymahs opinion, who adopts Muhammad bin Aslam al-Țsis statement, that the persons sound (sawt al-musawwit) is also the word of God like the Quran itself. Bayhaqi marked this opinion as "a terrible statement (ibarah radiah)". He then narrated a historical incident in which Ibn Abi Hatim al-Razi reportedly said: "What relation does Abu Bakr (Ibn Khuzaymah) have in theology? It is better for us and him to keep silent regarding something that we do not understand."

\section{Conclusion}

This paper has attempted to answer two key questions: First, how did al-Bayhaqi examine anthropomorphic terms in sifat traditions as articulated in his book al-Asma wa al-Sifat? After learning that his approach partially differs from most of his contemporary traditionalists, I then proceeded to the second question: why did he choose this new approach? I have answered the second question by describing the overall religious learning condition of his time. It is evident that his approach is influenced by the traditionalists perceived inability in defending Sunnism amidst unprecedented theological challenges. He shows disagreement with their rigorous anti-kalam approach in a changing context.

\section{References}

Adem, R. (2015). The Intellectual Geneology of Ibn Taymiya. (Doctoral database). Available from ProQuest Dissertations and Theses database. (UMI No. 3712006).

Al-Baghdadi, A. (1971). Sharaf Ashab al-Hadith. Ankara: Dar lhya al-Sunnah al-Nabawiyya.

Al-Baghdadi, A. (nd.) al-Faqih wa Al-Mutafaqih. Beirut: al-Maktabah Al-Ilmiyya.

Al-Bayhaqi, A. (1986). Bayan Khața Man Akhtaa Ala al-Shafii. Beirut: Muasasah al-Risalah.

Al-Bayhaqi, A. (1988). al-ltiqad wa al-Hidayah lla Sabil al-Rashad. Beirut: Dar al-Kitab al-Arabi.

Al-Bayhaqi, A. (2002). al-Asma Wa al-Sifat. Beirut: Dar al-Kitab al-Arabi.

Al-Bayhaqi, A. (2007). Risalah al-Imam al-Bayhaqi ila al-Imam Abi Muhammad al-Juwayni. Beirut: Dar al-Bashair al-Islamiyya.

Al-Bayhaqi, A. (nd.) Manaqib al-Shafii. Cairo: Maktaba Dar al-Turath.

Al-Darimi, U. (2014). Naqd al-Darimi ala Bishr al-Marisi al-Anid. Medina: Dar al-Nasiha.

Al-Dhahabi, A. (1986). Siyar Alam al-Nubala. Beirut: Muassasah ar-Risalah.

Al-Dhahabi, A. (1990). Tarikh al-Islam wa Wafayat al-Mashahir wa al-Alam. Beirut: Dar al-Kitab alArabi.

Al-Farra, M. (1410 H). Ibțal al-Tawilat li Akhbar al-Sifat. Kuwait: Dar al-Ilaf al-Duwaliyya.

Al-Fullani, S. (1328). Qațfal-Thimar fi Raf Asanid al-Musannafat fi al-Funun wa al-Athar. Heydarabad: Dairah al-Ma arif al-Niz̧amiyya. 
INTERNATIONAL JOURNAL OF ACADEMIC RESEARCH IN BUSINESS AND SOCIAL SCIENCES

Vol. 9, No. 6, June, 2019, E-ISSN: 2222-6990 @ 2019 HRMARS

Al-Ghamidi, A. (2002). al-Bayhaqi wa Mawqifuh min al-Ilahiyyat. Medina: al-Jamiah al-Islamiyya. Al-Jawzi, A. (1992). Al-Muntazam fi Tarikh al-Muluk wa al-Umam. Beirut: Dar al-Kutub al-Ilmiyya. Al-Khattabi, H. (1932). Maalim al-Sunan. Aleppo: np.

Al-Khattabi, H. (2004). al-Ghunyah an al-Kalam. Cairo: Dar al-Minhaj.

Al-Muallimi, A. (2001). al-Tankil bima fi Tanib al-Kawthari min al-Abatil. Riyad: Maktabah al-Maarif li al-Nashr wa al-Tauzi.

Al-Murtaḍa, A. (1961). Kitab Tabaqat al-Mutazilah. Beirut: np.

Al-Ramahurmuzi, H. (1984). al-Muhaddith al-Fasil Bayna ar-Rawi wa al-Wai. Beirut: Dar al-Fikr.

Al-Subki, A. (1999). Tabaqat al-Shafiiyyah al-Kubra. Beirut: Dar al-Kutub Al-Ilmiyya.

El-Omari, R. (2012). Accommodation and Resistance: Classical Mu'tazilites on Hadith. Journal of Near Eastern Studies 71 (2), 231-256

Furak, M. (2005). Mujarrad Maqalat al-Shaykh al-Ashari. Cairo: Maktabah al-Thaqafa al-Diniyya.

Gunther, S. (2008). In our days, religion has once again become something alien. The American Journal of Islamic Social Sciences 25 (3), 1-30.

Holtzman, L. (2010). "Does God Really Laugh?" Appropriate and Inappropriate Descriptions of God in Islamic Traditionalist Theology, in Albrecht Classen (ed.), Laughter in the Middle Ages and Early Modern Times, Berlin: De Gruyter.

Khalifah, H. (nd.) Kashf al-Zunun an Asami al-Kutub wa al-Funun. Beirut: Dar al-Kutub al-Ilmiyya.

Khuzaymah, M. (1992). Kitab al-Tawhid wa Ithbat Sifat al-Rabb. Beirut: Dar al-Kutub al-IImiyya.

Makdisi, G. (1962). Ash'ari and the Asharites in Islamic Religious History I. Studia Islamica 17, 37-80.

Ovadia, M. (2018). Ibn Qayyim al-Jawziyya and the Divine Attributes. Leiden: Brill.

Qutaybah, A. (1985). Al-Ikhtilaf fil-Lafz wa al-Radd ala Al-Jahmiyya wa al-Mushabbiha. Beirut: Dar alKutub Al-Ilmiyya.

Tokatly, V. (2001). The Alam Al-ḥadith of Al-Khațțabi: A Commentary on Al-Bukharis Sahih or a Polemical Treatise? Studia Islamica, 92, 53-91.

Widigdo, M. (2007). Nishapuri scholars in the formation of sunni Islam. Journal of Islamic Studies 2 (55).

Williams, W. (2009). A body unlike bodies: Transcendent Anthropomophism in Ancient semitic Tradition and Early Islam. Journal of American Oriental Society 129 (1). 